\title{
ChARACTERIZATION OF PROTECTIVE IMMUNITY INDUCED AGAINST SCHISTOSOMA MANSONI VIA DNA PRIMING WITH THE LARGE SUBUNIT OF CALPAIN (SM-P80) IN THE PRESENCE OF GENETIC ADJUVANTS
}

\author{
SIDDIQUI A.A.***, PINKSTON J.R.*, QUINLIN M.L.*, KAVIKONDALA V.*, REWERS-FELKINS K.A.***, \\ PHILLIPS T.* \& POMPA J.*
}

\section{Summary:}

Despite advances in control via snail eradication and large-scale chemotherapy using praziquental, schistosomiasis continues to spread to new geographic areas particularly in sub-Saharan Africa. Presently, there is no vaccine for controlling this disease. We have concentrated on a functionally important schistosome antigen Sm-p80 as a possible vaccine candidate for schistosomiasis. Here we report the proliferation of spleen cells in response to the recombinant $\mathrm{Sm}-\mathrm{p} 80$ protein and cytokine (IFN- $\gamma$ and $(\mathrm{L}-4)$ production by the splenocytes. These spleen cells were obtained from groups of mice that were vaccinated with a DNA vaccine formulation containing Sm-p8O and one of the Th-1 (IL-2 or IL-12) or Th-2 (GM-CSF, IL-4) enhancer cytokines. The splenocytes from the groups of mice vaccinated with Sm-p80 DNA in the presence of Th-2 enhancer cytokines showed moderate but detectable proliferation. The splenocytes obtained from mice vaccinated with Sm-p80 DNA with Th-1 enhancer cytokines IL-2 and IL-12 provided the highest proliferation. The IFN $-\gamma$ production by splenocytes was found to follow the similar pattern $[(\mathrm{Sm}-\mathrm{p} 80)<(\mathrm{Sm}-\mathrm{p} 80+\mathrm{IL}-4)<(\mathrm{Sm}-\mathrm{p} 80+\mathrm{GM}-\mathrm{CSF})$ $<(\mathrm{Sm}-\mathrm{p} 80+\mid \mathrm{L}-12)<(\mathrm{Sm}-\mathrm{p} 80+\mathrm{IL}-2)]$, as has been observed for the proliferation and protection data. However, the elevated IL-4 production was inversely correlated to Sm-p80-induced splenocyte proliferation or the protection. These results show again that protective immune response induced by Sm-p80 is of Th-1 type.

KEY WORDS : schistosomiasis, vaccine, Sm-p80 protein.
Résumé : CARACTÉRISATION D'UNE PROTECTION IMMUNITAIRE CONTRE SCHISTOSOMA MANSONI INDUITE PAR L'ADN AVEC LA SOUS-UNITÉ SM-P80 ASSOCIÉE À DIVERS ADJUVANTS

Malgré les progrès dans son contrôle par les campagnes d'éradication de mollusques et de chimiothérapie par le praziquantel à grande échelle, la schistosomiase continue de toucher de nouvelles zones géographiques, notamment en Afrique sub-saharienne. Aucun vaccin n'est disponible actuellement pour contrôler la maladie. Nous nous sommes intéressés à l'importante activité antigénique de la protéine $\mathrm{Sm-p80}$ en tant que candidat potentiel à une vaccination contre la schistosomiase. Nous rapportons ici la prolifération des cellules spléniques en réponse à la protéine recombinante $\mathrm{Sm}-\mathrm{p} 80$, et la production de cytokines (IFN- $\gamma$ et IL-4) par les splénocytes. Ces cellules spléniques ont été obtenues chez des groupes de souris vaccinées par une formulation à base d'ADN composée de Sm-p80 et de cytokines Th-1 (IL-2 ou IL-12) ou Th-2 (GM-CSF, IL-4). On observe une prolifération modérée, mais décelable, des splénocytes du groupe des souris vaccinées par Sm-p80 en présence de cytokines Th-2, et une plus importante prolifération des splénocytes des souris vaccinées par Sm-p80 en présence de cytokines Th- 7 (IL-2 et IL12). La production d'IFN- $\gamma$ par les splénocytes a suivi le même modèle $[(S m-p 80)<(S m-p 80+(L-4)<(S m-p 80+$ GM-CSF $)$ $<(S m-p 80+(L-12)<(S m-p 80+\mid L-2)]$ que ce qui a été constaté avec les données concernant la prolifération et la protection. Cependant, l'élévation de la production d'll-4 a été inversement proportionnelle à la prolifération de splénocytes induite par Smp80 et à la protection. Ces résultats montrent encore que la réponse immunitaire induite par $\mathrm{Sm-p} 80$ est de type Th- 7 .

MOTS CLÉS : schistosomiase, vaccin, protéine Sm-p80.

\section{INTRODUCTION}

Tr $\mathrm{t}$ is widely believed that a schistosomiasis vaccine would make an enormous contribution to current methods of control, particularly if it provides a potent, long-lasting immunity to the disease (Capron et al., 2002; Pearce, 2003; Hagan \& Sharaf, 2003).

\footnotetext{
* Department of Internal Medicine, Texas Tech University Health Sciences Center.

*** Veterans Affairs Health Care System, Amarillo, TX 79106, USA. Correspondence: Afzal A. Siddiqui, Ph.D., Texas Tech Women's Health \& Research Institute, 1400 Wallace Blvd., Amarillo, Texas 79106-1791, USA.

Tel.: (806) 354-5524 - Fax: (806) 354-5791

E-mail: Afzal.Siddiqui@ttuhsc.edu
}

However, a major problem that has hindered schistosomiasis vaccine research and development concerns the identification and selection of potential protective antigens encoded by the parasite. Recent studies have amplified these concerns (Hagan \& Sharaf, 2003). Independent examination of the six "priority antigens" (paramyosin, glutathione S-transferase, fatty acid binding $14 \mathrm{kDa}$ protein, IrV-5, triose phosphate isomerase and Sm23) via a standard comparative World Health Organization delineated procedure, resulted in none of them providing the stated goal of $40 \%$ protection or better (Bergquist et al., 2002). This report highlights the continued and urgent need for an examination and assessment of additional schistosomiasis vaccine candidates. 
We have identified a novel schistosome protein that was originally identified to be involved in the surface membrane biogenesis (Siddiqui et al., 1993). This phenomenon has been considered to be one of the mechanisms utilized by blood-dwelling helminths to evade the protective host immune response (Podesta et al., 1987; Siddiqui et al., 1993). This protein designated calpain, has two subunits, the larger of which, called Sm-p80 has been demonstrated to protect up to $60 \%$ against cercarial challenge when administered to mice in a DNA vaccine formulation (Siddiqui et al., 2003a, b).

In the present study, we report the in vitro proliferation of splenocytes in response to the recombinant Smp80 protein as well as cytokine production by these cells. These splenocytes were obtained from groups of mice that were vaccinated with a DNA vaccine formulation containing Sm-p80 and one of the Th-1 (IL2 or IL-12) or Th-2 (GM-CSF, IL-4) enhancer cytokines.

\section{MATERIALS AND METHODS}

\section{IMMUNIZATION PROTOCOLS}

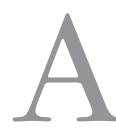
s described earlier (Siddiqui et al., 2003 a, b), to determine the protective effect of the large subunit of $S$. mansoni calpain, each mouse (C57BL/6 mice, 3-4 weeks old, 10-12 g) was primed with $100 \mu \mathrm{g}$ Sm-p80-pcDNA3. First and second boosts (100 $\mu \mathrm{g}$ Sm-p80-pcDNA3 each time) were given at 4 and 8 weeks, respectively. Each mouse in the control group received $100 \mu \mathrm{g}$ pcDNA3 on day 1 , followed by two injections of $100 \mu \mathrm{g}$ each, at week 4 and 8 , as above. Similar immunization regimen was also followed to test the adjuvant effects of GM-CSF, IL-4, IL2 and IL-12. Briefly, each mouse in the "cytokine group" received $100 \mu \mathrm{g}$ pORF-mGM-CSF or pORFmIL- 4 or pORF-mIL-2 or pORF-mIL-12 and $100 \mu \mathrm{g}$ Smp80-pcDNA3 on day 1, and two boosters of the exact same concentration and composition, 4 weeks part, as above. The control mice of the "cytokine group" received only $100 \mu \mathrm{g}$ pcDNA3. Four weeks after, the second boost, all of the mice from the groups outlined above, were challenged with 150 cercariae. The mice were sacrificed six weeks after challenge; adult worms were recovered from each mouse and percent reduction in worm burdens in vaccinated verses control animals was calculated (Siddiqui et al., 2003a, b). Each group of mice contained at least 15 animals.

\section{SPLENOCYTE PROLIFERATION ASSAYS}

The spleens from the five groups of mice, outlined above, were processed as follows: each spleen was removed aseptically then meshed through a fine screen in $6 \mathrm{ml}$ of RPMI 1640 medium (Invitrogen Corporation, Carlsbad, CA) containing $10 \%$ fetal bovine serum (FBS). The splenocytes were collected via centrifugation at $1,000 \times \mathrm{g}$ for $15 \mathrm{~min}$. The resultant pellet was then resuspended in $1 \mathrm{ml}$ Opti-Freeze DMSO Cryopreservation Medium (Fisher Scientific, Hampton, NH), placed in $-85^{\circ} \mathrm{C}$ overnight and finally stored at $-135^{\circ} \mathrm{C}$ until used.

The day of assay, the cells were thawed, washed in $9 \mathrm{ml}$ of RPMI 1640 medium containing $10 \%$ FBS and the cells were collected by centrifugation at 1,000 $\times \mathrm{g}$ for $15 \mathrm{~min}$ and the final pellet was resuspended in the medium. The viability of cells was determined via Trypan Blue, $>80 \%$ of cells were found to be viable. In a 96-well flat-bottom plate, the splenocytes $\left(5 \times 10^{5}\right.$ cells/100 $\mu \mathrm{l} /$ well) were stimulated with baculovirus generated Sm-p80 recombinant protein $(1.2 \mu \mathrm{g} /$ $100 \mu \mathrm{l} /$ well) (Siddiqui et al., 2003a). ConA was used at a concentration of $0.1 \mu \mathrm{g} /$ well. All assays were performed in triplicate wells. The plates were incubated at $37^{\circ} \mathrm{C}$ in $5 \% \mathrm{CO}_{2}$-humidified incubator. After $24 \mathrm{~h}$ incubation, $20 \mu \mathrm{l}$ of AlamarBlue (AB) reagent [(BioSource International, Camarillo, CA) (Ahmed et al., 1994)] was added and the plates were incubated again as above for up to $72 \mathrm{hrs}$. The plates were read at 24 , 48 and $72 \mathrm{hrs}$ at $570 \mathrm{~nm}$ and $630 \mathrm{~nm}$.

The reduction of $\mathrm{AB}$ was monitored spectrophotometrically according to the manufacturer's instructions and the reduction was expressed as a percentage (\% reduced). Briefly, the calculation of $\%$ reduced is as follows when the samples are read at: $\lambda 1=570 \mathrm{~nm}$, $82=600 \mathrm{~nm}$.

$\%$ reduced $=\frac{\left(\varepsilon_{\mathrm{ox}} \lambda 2\right)(\mathrm{A} \lambda 1)-\left(\varepsilon_{\mathrm{ox}} \lambda 2\right)(\mathrm{A} \lambda 2)}{\left(\varepsilon_{\mathrm{red}} \lambda 1\right)\left(\mathrm{A}^{\prime} \lambda 2\right)-\left(\varepsilon_{\mathrm{red}} \lambda 2\right)\left(\mathrm{A}^{\prime} \lambda 1\right)} \times 100$

Where: $\left(\varepsilon_{\text {red }} \lambda 1\right)=155,677$ (Molar extinction coefficient of reduced $\mathrm{AB}$ at $570 \mathrm{~nm}) ;\left(\varepsilon_{\text {red }} \lambda 2\right)=14,652$ (Molar extinction coefficient of reduced $\mathrm{AB}$ at $600 \mathrm{~nm}) ;\left(\varepsilon_{\mathrm{ox}} \lambda 1\right)$ $=80,586$ (Molar extinction coefficient of oxidized $\mathrm{AB}$ at $570 \mathrm{~nm}) ;\left(\varepsilon_{\mathrm{OX}} \lambda 2\right)=117,216$ (Molar extinction coefficient of oxidized $\mathrm{AB}$ at $600 \mathrm{~nm}) ;(\mathrm{A} \lambda 1)=$ Absorbance of test wells at $570 \mathrm{~nm} ;(\mathrm{A} \lambda 2)=$ Absorbance of test wells at $600 \mathrm{~nm} ;\left(\mathrm{A}^{\prime} \lambda 1\right)=$ Absorbance of negative control wells which contain medium plus $\mathrm{AB}$ but to which no cells have been added at $570 \mathrm{~nm}$; (A` $\lambda 2$ ) $=$ Absorbance of negative control wells which contain medium plus $\mathrm{AB}$ but to which no cells have been added at $600 \mathrm{~nm}$.

\section{ESTIMATION OF CYTOKINE PRODUCTION BY PROLIFERATING SPLENOCYTES}

To quantify the cytokine production by the proliferating splenocytes, exact duplicate wells were run simul- 
taneously, as described above. After $48 \mathrm{hrs}$ of incubation, the medium was collected from each well and stored at $-70^{\circ} \mathrm{C}$. Productions of cytokines by proliferating splenocytes was determined via BD OptEIA ELISA kits for mouse IL- 4 and mouse IFN- $\gamma$ (BD Biosciences Pharmingen, San Diego, CA), according to the manufacturer's instructions.

\section{STATISTICAL ANALYSIS}

Comparisons of cellular immune responses among groups of mice were performed by two-tailed $t$ test for two groups of animals or by analysis of variance (ANOVA) for more than two groups. Bonferroni adjustments were included for multiple comparisons, to reduce the risk of reaching false conclusions based on chance. In all cases, $P$ values $<0.05$ were considered significant.

\section{RESULTS AND DISCUSSION}

$\tau \mathrm{n}$ n this study we have determined the proliferative responses and production of cytokines via Alamar Blue assays (Ahmed et al., 1994) using frozen spleen cells (Wright et al., 2002) from five groups of mice. The groups of mice used in this study were vaccinated with a DNA vaccine formulation as described earlier (Siddiqui et al., 2003a, b) and were as follows: Group 1 (Sm-p80-pcDNA3), Group 2 (Sm-p80-pcDNA 3 + pORFmGM-CSF), Group 3 (Sm-p80-pcDNA3 + pORF-mIL-4), Group 4 (Sm-p80-pcDNA3 + pORF-mIL-12) and Group 5 (Sm-p80-pcDNA3 + pORF-mIL-2).

The splenocytes from the vaccinated groups proliferated significantly higher than compared to their respective controls when stimulated in vitro with Sm-p80 protein (Figs 1-3). However, Sm-p80 driven proliferation of splenocytes was markedly lower when compared to the stimulation induced by ConA (Figs 1-3). The splenocytes from the groups of mice vaccinated with Sm-p80 DNA in the presence of Th-2 enhancer cytokines showed moderate but detectable proliferation (Fig. 2). The splenocytes obtained from mice vaccinated with Sm-p80 DNA with Th-1 enhancer cytokines IL-2 and IL-12 provided the highest proliferation (Fig. 3). Specifically, the splenocytes from the Sm-p80pcDNA vaccinated group exhibited a $12 \%$ higher proliferation compared to their controls $(P<0.001)$ (Fig. 1). The introduction of GM-CSF and IL-4 in the DNA vaccine formulation increased this proliferation by splenocytes to $17 \%(P<0.001)$ and $16 \%$ $(P<0.001)$, respectively (Fig. 2$)$. As shown in Fig. 3, the highest degree of splenocyte proliferation was observed in the IL-12 group [21\% $(P<0.001)]$ and IL2 group $[23 \%(P<0.001)]$. The splenocyte proliferation was found to follow the similar pattern [(Sm-p80) $<($ Sm-p80 + IL-4) $<$ (Sm-p80 + GM-CSF $)<($ Sm-p80

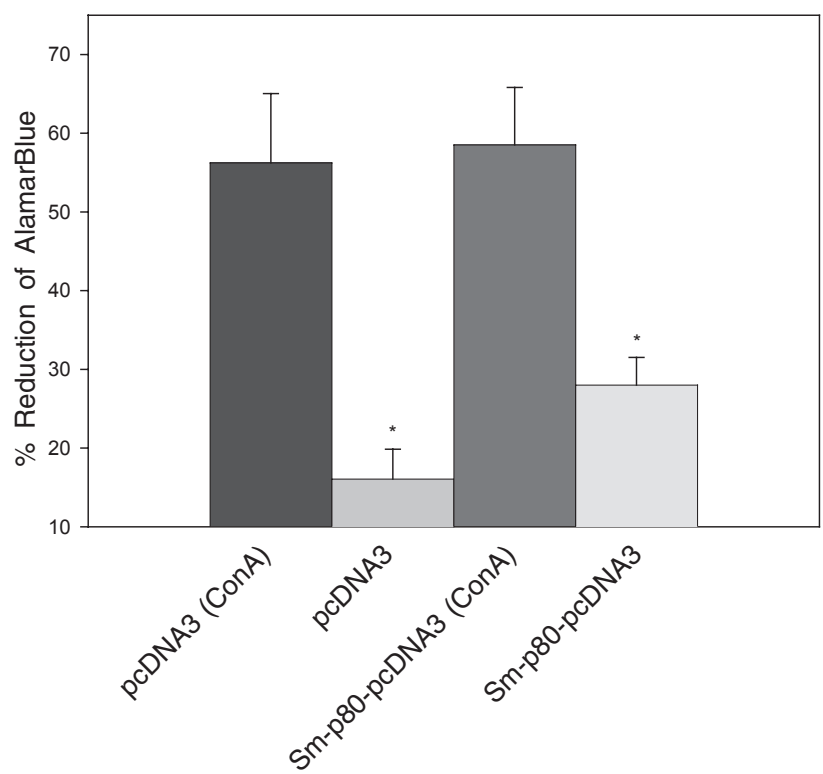

Fig. 1. - Proliferative responses by splenocytes to recombinant $\mathrm{Sm}$ p80. Spleens were obtained from mice immunized with pcDNA3 or Sm-p80-pcDNA3. Results are expressed as \% reduction of AlamarBlue after 48 hrs of cultures. ( $P<0.001)$.

+ IL-12) < (Sm-p80 + IL-2), as has been observed for the protection data (Siddiqui et al., 2003a, b). Briefly, Sm-p80 by itself provided a $39 \%$ protection against challenge infection in C57BL/6 mice (Siddiqui et al., 2003a, b). Co-injection of plasmid DNA encoding IL4 with Sm-p80 DNA yielded a protection level of $42 \%$ (Siddiqui et al., 2003b). The protection was found to be $44 \%$ when plasmid encoding GM-CSF was CO-administered with Sm-p80 DNA (Siddiqui et al., 2003a). Coinjection of plasmid DNA encoding IL-12 with Sm-p80 DNA yielded a protection level of $45 \%$ (Siddiqui et al., 2003b). This protection was increased to $57 \%$ when plasmid DNA encoding IL-2 was co-administered with Sm-p80 DNA (Siddiqui et al., 2003b).

As shown in Table I, the degree of proliferation was also correlated by the IFN- $\gamma$ production. The IFN- $\gamma$ production by splenocytes was found to follow the similar trend $[(\mathrm{Sm}-\mathrm{p} 80)<(\mathrm{Sm}-\mathrm{p} 80+\mathrm{IL}-4)<(\mathrm{Sm}-\mathrm{p} 80+\mathrm{GM}-$ $\mathrm{CSF})<($ Sm-p80 + IL-12) $<($ Sm-p80 + IL-2) , as has been observed for the proliferation and protection data (Siddiqui et al., 2003a, b). Conversely, the elevated IL-4 production (Table I) did not positively influence either the splenocyte proliferation or the protection.

Both the splenocyte proliferation profiles and the cytokine production data are in agreement with our previous findings in which immunization with Sm-p80 alone resulted in the elevation of $\operatorname{IgG}_{2 \mathrm{~A}}$ and $\operatorname{IgG}_{2 \mathrm{~B}}$ titers, a clear indication that a predominantly Th- 1 type of antibody response was induced by this antigen (Siddiqui et al., 2003b). This inclination towards a Th-1 type response following intramuscular injections of plasmid DNA is now widely accepted as an important 

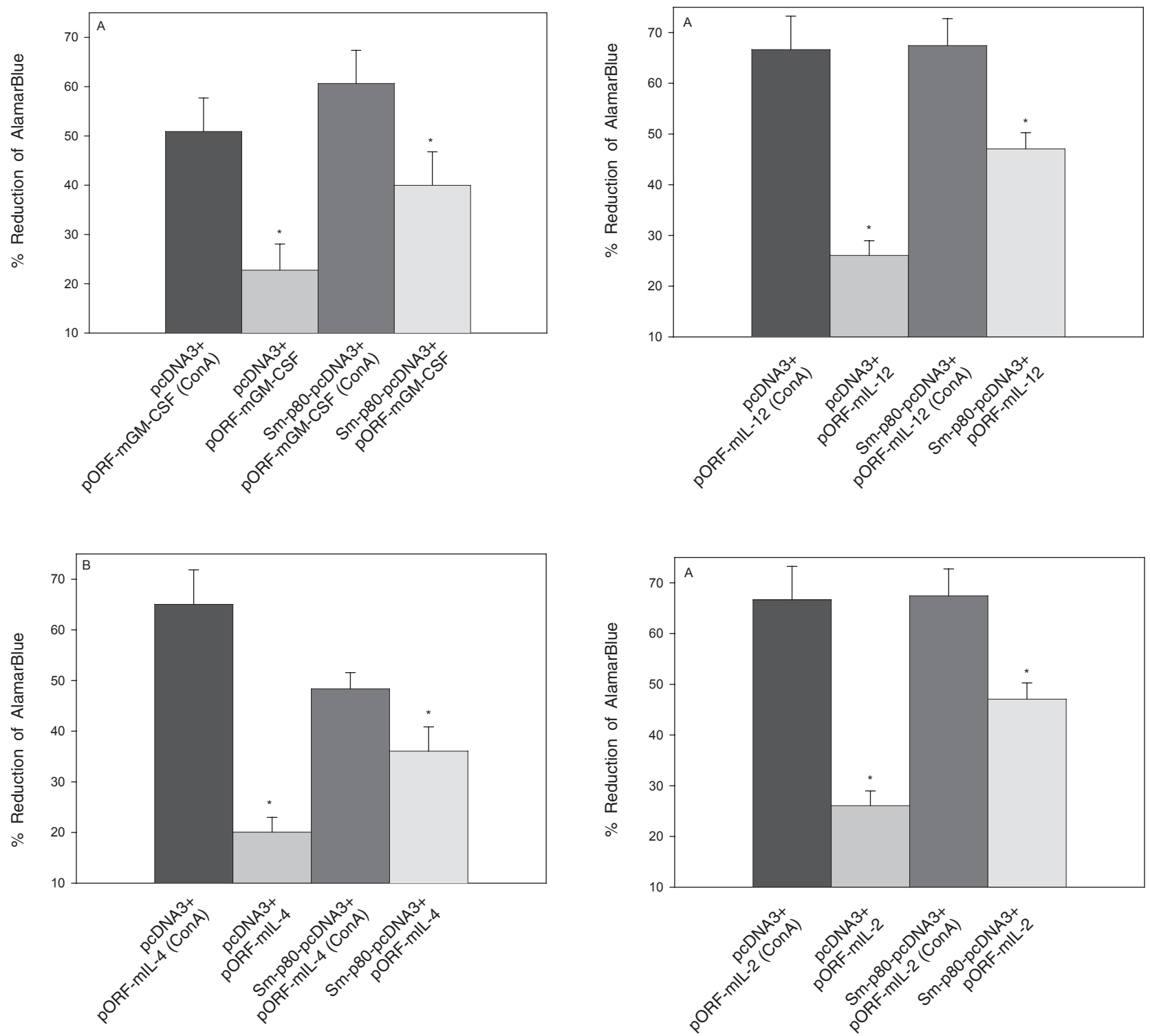

Fig. 2. - In vitro proliferative of spleen cells to recombinant Sm-p80 following $48 \mathrm{hr}$ cultures. The spleens were obtained from mice vaccinated with (A) Sm-p80-pcDNA3 plus pORF-mGM-CF and (B) Smp80-pcDNA3 with pORF-mIL-4. $(* P<0.001)$.

Fig. 3. - Splenocyte proliferation induced by recombinant Sm-p80 after 48 hrs of culturing in vitro. The spleens were obtained from mice inoculated with (A) Sm-p80-pcDNA3 plus pORF-mIL-12 and (B) Sm-p80-pcDNA3 with pORF-mIL-2. $\left({ }^{*} P<0.001\right)$.

Table I. - In vitro secretion of IFN- $\gamma$ and IL- 4 by lymphocytes ( $48 \mathrm{hrs)}$ from different groups of vaccinated mice

\begin{tabular}{lcr}
\hline Vaccine groups & $\begin{array}{c}\text { IFN- } \boldsymbol{\gamma} \\
(\mathbf{p g} / \mathbf{m l} \pm \mathbf{S D})\end{array}$ & $\begin{array}{c}\mathbf{I L}-\mathbf{4} \\
(\mathbf{p g} / \mathbf{m l} \pm \mathbf{S D})\end{array}$ \\
\hline Sm-p80-pcDNA3 & $415 \pm 27.9$ & $171 \pm 23.2$ \\
Sm-p80-pcDNA3 + pORF-mGM-CSF & $488 \pm 37.9$ & $134 \pm 12.1$ \\
Sm-p80-pcDNA3 + pORF-mIL-4 & $400 \pm 38.1$ & $245 \pm 13.6$ \\
Sm-p80-pcDNA3 + pORF-mIL-12 & $1,071 \pm 54.3$ & $43 \pm 2.3$ \\
Sm-p80-pcDNA3 + pORF-mIL-2 & $1,415 \pm 122.9$ & $46 \pm 1.5$ \\
\hline
\end{tabular}

characteristic of naked DNA vaccinations (Min et al., 2002). Furthermore, co-inoculation of Sm-p80 with GM-CSF resulted in augmentation of total IgG and $\operatorname{IgG}_{1}$ antibody titers, indicating that Th- 2 arm of the immune system was also induced. Interestingly, however, $\operatorname{IgG}_{2 \mathrm{~A}}$ titers remained high but $\operatorname{IgG}_{2 \mathrm{~B}}$ titers were reduced (Siddiqui et al., 2003a). Elevation of $\operatorname{IgG}_{2 \mathrm{~A}}$ titers suggested that either GM-CSF was unable to counter the already biased Th-1 type response induced by intramuscular injections of plasmid DNA containing Th-1 promoting 
unmethylated $\mathrm{CpG}$ sequence motifs or GM-CSF was capable of inducing both Th- 1 and Th- 2 types of responses, as discussed previously (Scott \& Hunter, 2002). Similarly, simultaneous administration of the DNA vaccine with plasmid DNA encoding GM-CSF has been shown to activate both a Th- 1 and a Th-2 response (Wiess et al., 1998; Kusakabe et al., 2000). Intramuscular injections of Sm-p80 with IL-4 resulted in a very little enhancement of $\operatorname{IgG}_{1}$ titers but $\operatorname{IgG}_{3}$ titers were found to be quite elevated (Siddiqui et al., 2003a). However, this combination of plasmid DNA was not able to reduce or negatively affect the levels of total $\operatorname{IgG}, \operatorname{IgG}_{2 \mathrm{~A}}$ and $\mathrm{IgG}_{2 \mathrm{~B}}$, elicited by intramuscular injections of Sm-p80 DNA (Siddiqui et al., 2003b). These findings suggested that the effect of DNA vaccination is dominant over any effect of co-administered IL-4. Similar results were found with another schistosome antigen Sm23 DNA (Da'dara et al., 2000 a, b). Addition of plasmid DNA encoding IL-2 with Sm-p80 resulted in marked enhancement of total $\operatorname{IgG}$ and its subtypes $\operatorname{IgG}_{2 \mathrm{~A}}$ and $\operatorname{IgG}_{2 \mathrm{~B}}$ titers when compared with antibody profiles from Sm-p80 alone group (Siddiqui et al., 2003b). Furthermore, introduction of plasmid DNA encoding IL-12 with Sm-p80 augmented only total IgG and $\operatorname{IgG}_{2 \mathrm{~A}}$ titers when compared with Sm-p80 alone group (Siddiqui et al., 2003b). Taken together, data obtained in this study reinforces our pervious findings (Siddiqui et al., 2003a, b), on antibody titers and induction Th-1 type response by Sm-p80.

In summary, our results with Sm-p80 and of others with another schistosome antigen Sm23 (Da'Dara et al., 2003), it is becoming evident that to achieve good protection against cercarial challenge, a dominant Th- 1 type of response is required, at least in the murine model. The efficacy of both of these antigens is greatly reduced when using protocols that diminish Th- 1 type of response (Siddiqui et al., 2003; Da'Dara et al., 2000a, b; 2003). As per the WHO-TDR recommendations (> $50 \%$ consistent protection in mice) Sm-p80 is now ready to be taken into human phase I trials, but we strongly believe that this or any other schistosome antigen should not be rushed pre-maturely as has been the case with other "priority antigens". Therefore, we are presently testing the protective and therapeutic potential of Sm-p80 in non-human primates. Furthermore, studies are also underway to test the vaccine effect of Smp80, using different strains of mice to detect a potential "host genetic effect" on the level of protection

\section{ACKNOWLEDGEMENTS}

T This study was funded by a NIAID/NIH grant (1R15AI50534-01) to Afzal Siddiqui. A student stipend (Janet Pompa) was funded through a
NIAID-Research Supplement for Underrepresented Minorities in Biomedical Research (3R15AI50534-01S1) to Afzal Siddiqui.

\section{REFERENCES}

Ahmed S.A., Gogal R.M. \& Walsh J.E. A new rapid and simple non-radioactive assay to monitor and determine the proliferation of lymphocytes: an alternative to $\left[{ }^{3} \mathrm{H}\right]$ thymidine incorporation assay. Journal Immunology Methods, 1994, $170,211-224$.

Bergquist R., Al-sherbiny M.A., Barakat R. \& Olds R. Blueprint for schistosomiasis vaccine development. Acta Tropica, 2002, 82, 183-192.

Capron A., Riveau G.J., Bartley P.B. \& McManus D.P. Prospects for a schistosome vaccine. Prospects for a schistosome vaccine. Curr Drug Targets Immune Endocr Metabol Disord, 2002, 2, 281-290.

DA'DARA A.A., SKelly P.J., WANG M.M. \& HARn D.A. Immunization with plasmid DNA encoding the integral membrane protein, $\mathrm{Sm} 23$, elicits a protective immune response against schistosome infection in mice. Vaccine, 2002a, 20, 359369.

Da'dara A.A., Skelly P.J., Fatakdawala M., Visovatti S., ERIKSSON E. \& HARN D.A. Comparative efficacy of the Schistosoma mansoni nucleic acid vaccine, Sm23, following microseeding or gene gun delivery. Parasite Immunology, 2002b, 24, 179-187.

Da'dara A.A., Skelly P.J., Walker C.M. \& Harn D.A. A DNAprime/protein-boost vaccination regimen enhances Th2 immune responses but not protection following Schistosoma mansoni infection. Parasite Immunology, 2003, 25, 429-437.

Hagan P. \& Sharaf O. Schistosomiasis vaccines. Expert Opin Biol Ther, 2003, 3, 1271-1278.

Kusakabe K., Xin K.Q., Katoh H., Sumino K., Hagiwara E., Kawamoto S., Okuda K., Miyagi Y., AOKi I., Nishioka K., KLINMAN D. \& OKUDA K. The timing of GM-CSF expression plasmid administration influences the Th1/Th2 response induced by an HIV-1-specific DNA vaccine. Journal Immunology, 2000, 164, 3102-3111.

Min W., Lillehoj H.S., Burnside J., Weining K.C., Staeheli P. \& ZHU J.J. Adjuvant effects of IL-1 $\beta$, IL-2, IL-8, IL-15, IFN- $\alpha$, IFN- $\gamma$, TGF- $\beta 4$ and lymphotactin on DNA vaccination against Eimeria acervulina. Vaccine, 2002, 20, 267-274.

PeArce E.J. Progress towards a vaccine for schistosomiasis. Acta Tropica, 2003, 86, 309-313.

Podesta R.B., Karcz S., Ansell M. \& Silva E. Schistosoma mansoni: apical membranes/envelop synthesis, signal transduction and protein phosphorylation. In: Molecular Paradigms for Eradicating Helminthic Parasites. UCLA Symposia on Molecular Cellular Biology. MacInnis A.J., Liss A.R. (Eds), New York, 1987, 60, 241-255.

SCOTT P. \& Hunter C.A. Dendritic cells and immunity to leishmaniasis and toxoplasmosis. Curr Opin Immunol, 2002, 14, 466-470. 
Siddiqui A.A., Zhou Y., Podesta R.B., Karcz S.R., Tognon C.E., Strejan G.H., Dekaban G.A. \& Clarke M.W. Characterization of $\mathrm{Ca}(2+)$-dependent neutral protease (calpain) from human blood flukes, Schistosoma mansoni. Biochim Biophys Acta, 1997, 1181, 37-44.

Siddiqui A.A., Phillips T., Charest H., Podesta R.B., Quinlin M.L., Pinkston J.R., Lloyd J.D., Paz M., VillaLOVOS R.M. \& POMPA J. Induction of protective immunity against Schistosoma mansoni via DNA priming and boosting with the large subunit of calpain (Sm-p80): adjuvant effects of granulocyte-macrophage colony-stimulating factor and interleukin-4. Infect Immun, 2003a, 71, 38443851.

Siddiqui A.A., Phillips T., Charest H., Podesta R.B., Quinlin M.L., Pinkston J.R., Lloyd J.D., Pompa J., Villalovos R.M. \& PAZ M. Enhancement of Sm-p80 (large subunit of calpain) induced protective immunity against Schistosoma mansoni through co-delivery of interleukin-2 and interleukin-12 in a DNA vaccine formulation. Vaccine, 2003b, 21, 2882-2889.

Weiss W.R., Ishit K.J., Hedstrom R.C., Sedegah M., Ichino M., Barnhart K., Klinman D.M. \& Hoffman S.L. A plasmid encoding murine granulocyte-macrophage colony-stimulating factor increases protection conferred by malaria DNA vaccine. Journal Immunology, 1998, 161, 2325-2332.

Wright S.E., Rewers-Felkins K.A., Quinlin I.S., Eldridge P.W. \& Zorsky P.E., Klug P.P., Phillips C.A. \& Philip R. Adoptive immunotherapy of mucin1 expressing adenocarcinomas with mucin1 stimulated human peripheral blood mononuclear cells. International Journal Mol Med, 2002, 9, 401-404.

Reçu le 28 juillet 2004 Accepté le 30 septembre 2004 